\title{
Effects of green space dynamics on urban heat islands: Mitigation and diversification
}

\author{
Ranhao Sun ${ }^{1}$, Liding Chen ${ }^{* 2}$ \\ Research Center for Eco-Environmental Sciences, Chinese Academy of Sciences, 18 Shuangqing Road, Haidian District, Beijing 100085, People's Republic of \\ China
}

\section{A R T I C L E I N F O}

\section{Keywords:}

Land surface temperature

Temperature mitigation

Landscape pattern

Landscape design

Urbanization

\begin{abstract}
A B S T R A C T
Understanding how green spaces affect urban temperature is crucial for assessing thermal benefits of landscape planning. This study investigated green space dynamics and land surface temperature (LST) in the Beijing metropolis. Landscape types were classified from QuickBird (2002) and IKONOS (2012) images and LST values were extracted from Landsat TM images. Five landscape types were obtained in this region including impervious land (IL), forest land (FL), grass land (GL), water body (WB), and bare land (BL). Green expansion indicated landscape change from IL and BL to FL and GL. Green loss indicated landscape change from FL and GL to IL. Green exchange indicated landscape change between FL and GL. Results show that (1) the area of green space dynamics accounted for $38.24 \%$ of the total research area, including green space losses $\left(108.86 \mathrm{~km}^{2}\right)$, expansion $\left(92.49 \mathrm{~km}^{2}\right)$, and exchange $\left(53.83 \mathrm{~km}^{2}\right)$. (2) LST change was not significant in the unchanged $\left(0-0.19^{\circ} \mathrm{C}\right.$ ) and exchanged green space (in the range of $-0.02-0.25^{\circ} \mathrm{C}$ ). However, there were minor decreases of LST in areas of green expansion (in the range of $-1.11^{\circ} \mathrm{C}$ to $-0.67^{\circ} \mathrm{C}$ ) and major increases in LST in the areas of green losses $\left(1.64-2.21^{\circ} \mathrm{C}\right)$. The results indicated that the number of green spaces is not the only criteria that should be assessed for temperature mitigation. Ecosystem services of temperature mitigation are not equal between the loss and expansion of green spaces even within same area. Greater focus on protecting natural forests in cities might provide greater benefits for climate mitigation.
\end{abstract}

\section{Introduction}

Rapid urbanization leads to a significant transformation of green spaces to impervious surfaces and urban infrastructures (Holt et al., 2015; Liu and Yang, 2013). A large number of cities throughout the world have experienced "urban heat island" (UHI) effects. UHI are characterized by a temperature difference between urban and rural regions. In highly urbanized regions, urban sprawl is spatially heterogeneous due to land availability and management requirements. This heterogeneous urbanization creates a complex energy balance and microclimate system inside large cities (Oke, 1982). Thermal comfort decreases and energy consumption for cooling increases with the degradation of the thermal environment of cities. Thus, the urban resilience to heat waves is negatively affected (McPhearson et al., 2015). Urban green spaces can contribute to a broad range of ecosystem services, among which temperature mitigation is regarded as an important ecosystem regulating service (Braat and Groot, 2012; Riechers et al., 2016). Understanding the influences of green space dynamics on the temperature variability is therefore of great interest for mitigating the UHI effect in metropolitan regions (Buyantuyev and $\mathrm{Wu}, 2012)$.

The UHI effect can be assessed by measuring surface air temperature (SAT) (Schwarz et al., 2012; Wang et al., 2014) and land surface temperature (LST) (Buyantuyev and Wu, 2012; Cao et al., 2010; Rotem-Mindali et al., 2015). Studies have shown that LST was significantly correlated with SAT in the daytime (Nichol and Wong, 2008; Weng, 2009). Urban green infrastructure has been commonly used to address climate-related impacts and other environmental ills (Gaffin et al., 2012; Haase et al., 2014; Shashua-Bar and Hoffman, 2000; Yuan and Bauer, 2007). Green spaces can generate a cooling effect on LST via higher levels of evapotranspiration compared with impervious surfaces (Zhou et al., 2014; Zhao et al., 2014). Some research has shown that the mean LST was $6-12{ }^{\circ} \mathrm{C}$ higher for impervious surfaces compared to green spaces (Kuang et al., 2015). Other studies suggest that a $10 \%$ increase in green spaces could result in a $0.86^{\circ} \mathrm{C}$ decrease in LST (Li et al., 2012). The spatial variation of

\footnotetext{
* Corresponding author.

E-mail addresses: rhsun@rcees.ac.cn (R. Sun), liding@rcees.ac.cn (L. Chen).

${ }^{1} \mathrm{R}$. Sun will handle correspondence at all stages of refereeing and publication.

${ }^{2} \mathrm{~L}$. Chen will handle correspondence at the stage of post-publication.
} 
UHI from city center to outskirts is particularly significant in large metropolitan areas (Kuang et al., 2015; Zhang et al., 2013). Given the complex thermal background, green spaces could produce a different latent heat of evapotranspiration and thus result in diverse cooling effects during summer (Spronken-smith et al., 2000; Sun and Chen, 2012).

Landscape structure, such as the size, shape, and configuration, is another contributor to the surface heat flux and therefore affects temperature mitigation (Li et al., 2011; Lindberg and Grimmond, 2011; Peng et al., 2016; Zhou et al., 2011). Recent studies have shown that the spatial complexity of landscapes was important in maintaining the stability of LST throughout different seasons (Liu and Weng, 2008; Sun et al., 2013). The relationship between landscape structure and LST may vary among different landscape types (Connors et al., 2013). In some cities, the spatial structure of green spaces contributed more to the LST variation than the total area of green spaces (Asgarian et al., 2015; Chen et al., 2014).

Urban greening is often implemented to offset the negative impact of impervious surfaces on urban temperature. Although the areas of green spaces can be compensated quickly, the underlying mechanism of their cooling effect (e.g., vegetation activities and albedo) may be different among various types of green spaces. Different types of green space may exhibit different capabilities for temperature mitigation. To our knowledge, no studies have compared the change of LST based on different types of green spaces. Apparently, a more detailed assessment on the LST change and underlying mechanism is required for a better understanding of the climate mitigation. This study aims to determine whether two landscape types that are converted into the same landscape type will exhibit the same temperature and to identify what factors affect the benefits of urban greening in rapidly urbanized regions.

For this study, we selected the Beijing metropolis as a study case to investigate the mean LST of different landscape conversions. Beijing has experienced massive urban construction and greening since its successful bid for the 2008 Olympic Games in July 2001. Urban landscapes experienced more rapid changes in the $2000 \mathrm{~s}$ than any time in Beijing's history. Beijing should therefore be an ideal site to examine landscape conversion and associated thermal effects. We conducted this study to: (1) investigate the dominant combinations of landscape conversion in Beijing from 2002 to 2012 and (2) quantify the change of mean LST based on green space losses, expansion, and exchange.

\section{Materials and methods}

\subsection{Study area}

Beijing is the capital of China, covering an area of approximately $16,800 \mathrm{~km}^{2}$, and has experienced rapid development in recent decades. Beijing is characterized by a warm temperature zone and has a typical continental monsoon climate with four distinct seasons. The resident population of Beijing reached 20.69 million in 2012 (Wang et al., 2014). Rapid urbanization and city expansion resulted in significant UHI effects, particularly during the summer (Ding and Shi, 2013; Kuang et al., 2015; Li et al., 2012; Sun and Chen, 2012; Peng et al., 2016). The UHI intensity in Beijing has increased at a rate of $0.031{ }^{\circ} \mathrm{C}$ per year (Yu et al., 2005). The mean daily temperature in urban areas is $4.6{ }^{\circ} \mathrm{C}$ higher than the mean daily temperature in the suburbs (Song and Zhang, 2003). Moreover, urban construction and greening was primarily due to the stimulus provided by the hosting of the Olympic Games. The investment in Beijing Olympics exceeded $\$ 42.9$ billion and about $\$ 15.7$ billion was used in environmental protection projects to achieve the goal of "Green Olympics" (Chen et al., 2013; Zhang and Qian, 2010). The green spaces increased by $100 \mathrm{~km}^{2}$ from 2002 to 2008 and the green coverage reached $43.5 \%$ in the Beijing metropolis (Dong, 2009).
The pattern of Beijing's development was a typical concentric expansion, generating a ring-shaped pattern from the city center to outskirts. The urban construction and greening related to the Olympic Games was mostly located inside of the 5th ring-road (Kuang et al., 2015). Our study is targeted at the highly-urbanized region inside of the 5th ring-road of Beijing, which covers an area of $667.28 \mathrm{~km}^{2}$. This region is relatively flat, with elevations ranging from $20 \mathrm{~m}$ to $60 \mathrm{~m}$ above sea level. The study area was divided into four sub-regions via the ring-roads, including the sub-region inside of the 2nd ring-road, the sub-region between the 2nd and 3rd ring-roads, the sub-region between the 3rd and 4th ring-roads, and the sub-region between the 4th and 5th ring-roads.

\subsection{Landscape types}

Remote sensing images with high spatial resolution were used to identify landscape types in the Beijing metropolis. (1) QuickBird images were acquired on July 5, 2002 with 4 multi-spectral bands (2.44 $\mathrm{m}$ spatial resolution) and 1 panchromatic band $(0.61 \mathrm{~m})$. Furthermore, (2) IKONOS images were collected on July 29, 2012 with 4 multi-spectral bands ( $4 \mathrm{~m}$ ) and 1 panchromatic band $(1 \mathrm{~m})$. The image classification and change analysis were based on a $4 \mathrm{~m}$ spatial resolution. Geometric correction of QuickBird images was used to match the IKONOS images based on 40 control points. The spatial error between QuickBird and IKONOS images was less than $2 \mathrm{~m}(0.5$ pixel). These images were geo-referenced to the Universal Transverse Mercator (UTM) coordinate system with a first-order polynomial transformation. The images in 2002 represent the original landscape before rapid urbanization, and the images in 2012 exhibit the changed landscape after rapid urbanization in the Beijing metropolis.

We combined the unsupervised classification and decision tree methods to extract the landscape type using the ENVI software (Exelis Visual Information Solutions, Inc., USA). First, several clusters of landscape types were obtained based on the unsupervised classification method. These clusters were classified by the image reflectance and were manually checked to determine their landscape type. The panchromatic band and municipal thematic maps were used to help select sample regions for classification and verification. Second, some mixed clusters with water and shadow were reclassified via two indices, i.e., the normalized difference vegetation index (NDVI) and watershadow distinction index (WSDI). The NDVI was calculated from the near infrared and red bands, and the WSDI was developed via the near infrared, red, and green bands of multi-spectral images (Chen et al., 2014).

$\mathrm{NDVI}=\frac{\rho(\text { Band } 4)-\rho(\text { Band } 3)}{\rho(\text { Band } 4)+\rho(\text { Band } 3)}$

$\mathrm{WSDI}=\frac{\rho(\text { Band } 4)-\rho(\text { Band } 3)}{\rho(\text { Band } 2)-\rho(\text { Band } 3)}$

Where $\rho$ (Band 4, 3,2) represents top-of-atmosphere reflectance transformed from the digital value of remote sensing images. The thresholds of NDVI and WSDI was used to distinguish different landscape types. For example, the vegetation index $($ NDVI $>0)$ was used to identify the vegetation areas from non-vegetation areas. Water had a low WSDI $(<0.5)$ whereas shadow had a high WSDI $(0.5<$ WSDI < 1).

Five landscape types were obtained in this region based on the above classification procedures. They were impervious land (IL), forest land (FL), grass land (GL), water body (WB), and bare land (BL). Lastly, a standard procedure was applied to assess classification accuracy. Ground-truthing analysis was conducted by verifying 387 random points after classification. The correctness (producer's accuracy) of the QuickBird classification was $0.90,1.00,0.80,0.83$, and 0.81 for the impervious land, water, forest land, grass land, and bare land, respectively. The overall accuracy of the classification was $85.2 \%$, 


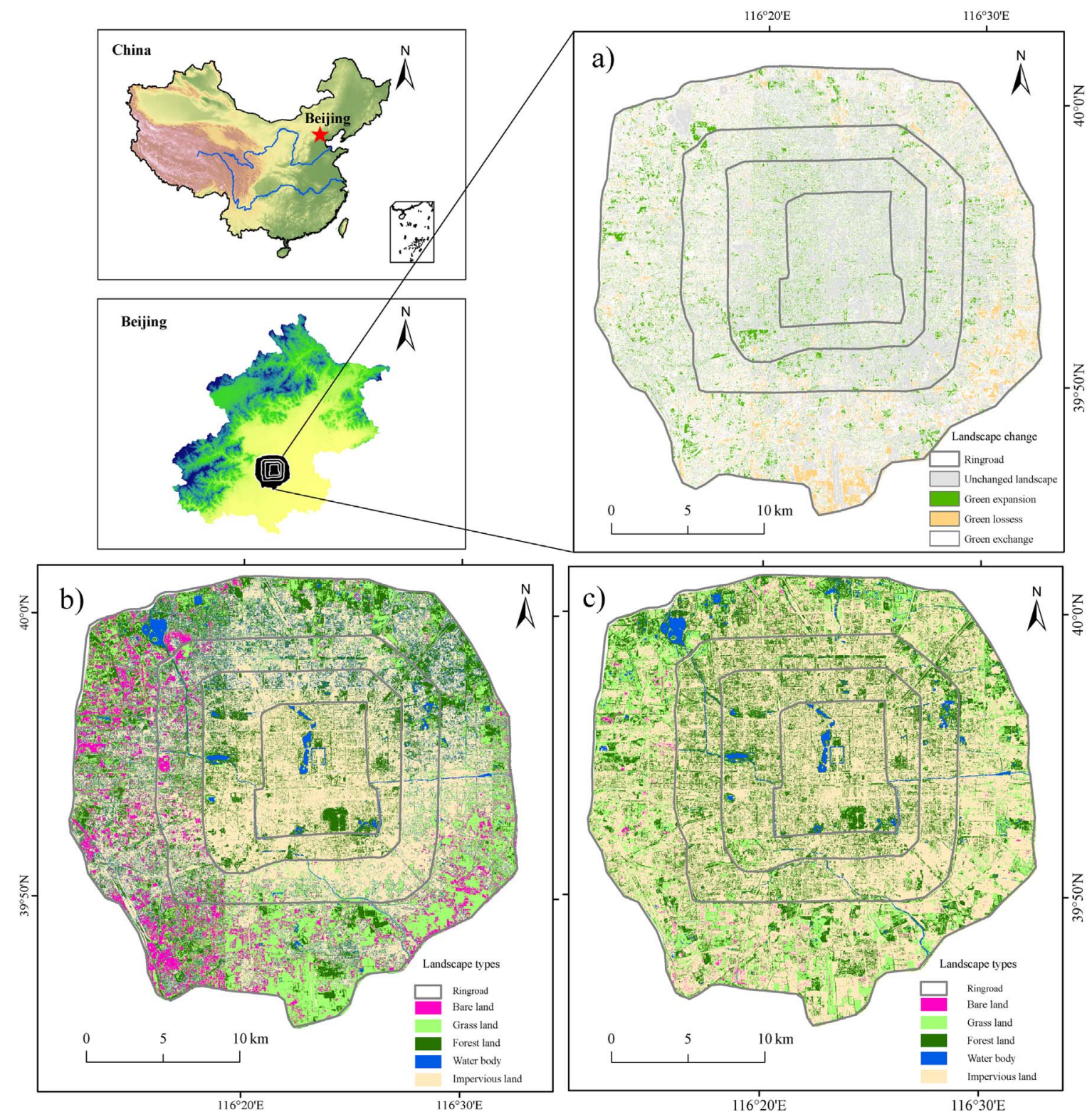

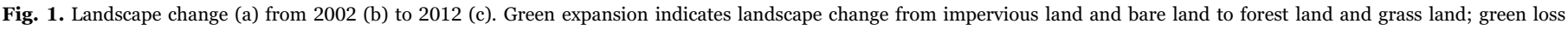
indicates landscape change from forest land and grass land to impervious land; and green exchange indicates landscape change between forest land and grass land..

and the kappa coefficient was 0.79 (Chen et al., 2014). The correctness of the IKONOS classification was $0.98,1.00,0.69,0.82$, and 0.35 for the impervious land, water, forest land, grass land, and bare land, respectively. The overall accuracy of the classification was $85.8 \%$, and the kappa coefficient was 0.75 (Yao et al., 2015). We analyzed the result of landscape conversion from 2002 to 2012 and found that the mean area of landscape units was $1293 \mathrm{~m}^{2}$. Therefore, we resampled the map of landscape conversion into a 30-m spatial resolution (Fig. 1).

\subsection{Landscape structure features}

Five landscape metrics were used to investigate the change in landscape structure from 2002 to 2012 (Table 1). These landscape metrics include percent of landscape (PLAND), largest patch index (LPI), mean patch size (MPS), area-weighted mean shape index (AWMSI), and interspersion and juxtaposition (IJI). These metrics were used to describe some important structural features, such as landscape area, complexity, and connectivity. The landscape metrics were calculated at the class level, based on the Fragstats software (McGarigal and Marks, 1995). The landscape location was assessed according to the distance from the city center of the Beijing metropolis.

\subsection{Land surface temperature}

Summers in Beijing are extremely warm and humid compared with other seasons and were chosen to examine the thermal environment and urban expansion (Peng et al., 2016). We selected the research dates according to weather conditions and the availability of remote sensing images. Five dates with $>30^{\circ} \mathrm{C}$ maximum air daytime temperatures were selected: July 9, 2002; July 20, 2009; August 8, 2010; June 8, 2011; and August 12, 2012. The weather conditions on the dates of remote sensing image acquisitions were collected from the National Meteorological Information Center, China Meteorological Administration (Table 2). The LST data was extracted from the thermal-infrared bands (120-m spatial resolution) of five cloud-free Landsat TM images (path 123, row 032). These images were geometrically rectified and converted to the UTM system. The thermalinfrared band was then resampled to a $30 \mathrm{~m}$ spatial resolution. The LST data was retrieved from the thermal-infrared band using existing methods (Jiménez-Muñoz and Sobrino, 2003; Peng et al., 2016; 
Table 1

Landscape metrics and calculation equations.

\begin{tabular}{|c|c|c|c|c|c|}
\hline $\begin{array}{l}\text { Structural } \\
\text { feature }\end{array}$ & Metric & Full name & Definition & Unit & Equation \\
\hline \multirow[t]{3}{*}{ Area and size } & PLAND & Percent of landscape & The percentage of each landscape class. & $\%$ & $P L A N D=P_{i}=\frac{\sum_{j=1}^{n} a_{i j}}{A}(100)$ \\
\hline & LPI & Largest patch index & The percent of the largest patch. & $\%$ & $L P I=\frac{\substack{n \\
\max \left(a_{i j}\right)}}{A}(100)$ \\
\hline & MPS & Mean patch size & Average patch size. & ha & $M P S=\frac{\sum_{j=1}^{n} a_{i j}}{n_{i}}\left(\frac{1}{10,000}\right)$ \\
\hline Complexity & AWMSI & $\begin{array}{l}\text { Area-weighted mean } \\
\text { shape index }\end{array}$ & $\begin{array}{l}\text { The sum of the perimeter of each patch divided by the square root of } \\
\text { the patch area for each class (class level) or for all patches (landscape } \\
\text { level). AWMSI is equal to } 1 \text { when all patches are circular or square and } \\
\text { it increases with greater patch shape irregularity. }\end{array}$ & none & $A W M S I=\sum_{j=1}^{n}\left[\left(\frac{p_{i j}}{2 \sqrt{\pi^{*} a_{i j}}}\right)\left(\frac{a_{i j}}{\sum_{j=1}^{n} a_{i j}}\right)\right]$ \\
\hline Connectivity & IJI & $\begin{array}{l}\text { Interspersion and } \\
\text { Juxtaposition Index }\end{array}$ & $\begin{array}{l}\text { IJI approaches zero when the distribution of unique patch adjacencies } \\
\text { becomes uneven and approaches } 100 \text { when all patch types are equally }\end{array}$ & $\%$ & $I J I=\frac{-\sum_{k=1}^{m^{\prime}}\left[\left(\frac{e_{i k}}{\sum_{k=1}^{m^{\prime}} e_{i k}}\right) \ln \left(\frac{e_{i k}}{\sum_{k=1}^{m^{\prime}} e_{i k}}\right)\right]}{(100)}$ \\
\hline
\end{tabular}

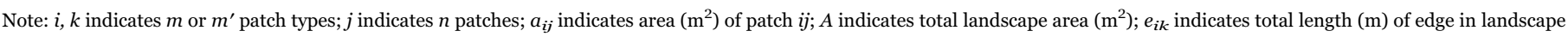

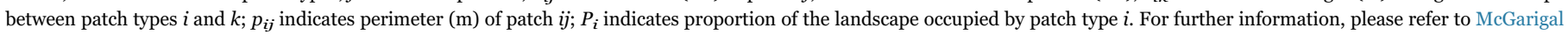
and Marks (1995).

Sobrino et al., 2004). The procedures for the LST retrieval included: (1) the conversion of the digital number to at-sensor radiance; (2) the calculation of at-sensor radiance to at-sensor temperature; and (3) the adjustment of at-sensor temperature to LST with land surface emissivity (Chen et al., 2014).

\subsection{Statistical analyses}

The relative values of LST (RLST) were used to compare the pattern of LST for different years (Fig. 2). The RLST was calculated via the LST of each cell and the mean LST of the entire study area.

$R L S T_{j}^{i}=L S T_{j}^{i}-L S T_{\text {mean }}^{i}$

where $R L S T_{j}^{i}$ indicates the relative temperature of cell $j$ of landscape $i$; $L S T^{i}{ }_{j}$ is the LST of cell $j$ of landscape $i$; and $L S T^{i}{ }_{\text {mean }}$ is the mean value of LST for landscape $i$. If $R L S T_{j}{ }^{i}>0$, then cell $j$ produces a positive contribution to the thermal environment. If $R L S T_{j}{ }^{i}<0$, then cell $j$ generates a negative contribution to the thermal environment. These analyses were conducted based on the cells of the raster data using ENVI software.

\section{Results}

\subsection{Green space dynamics}

Different combinations of landscape conversions were identified from 2002 to 2012 (Table 3). The unchanged area of impervious, water, forest, grass, and bare land was 251.02, 7.73, 57.4, 44.14, and $2.8 \mathrm{~km}^{2}$, respectively. The area of unchanged landscape accounted for $54.4 \%$ of the total research area. The impervious land, forest land, and water body areas increased by $80.63,25.05$, and $1.88 \mathrm{~km}^{2}$, respectively. The grass land area decreased by $45.12 \mathrm{~km}^{2}$ and bare land decreased by $62.45 \mathrm{~km}^{2}$. Most impervious land and water body in 2012 retained their original landscape types, accounting for $78.36 \%$ and $83.03 \%$ of their area in 2002, respectively. Only $46.7 \%$ and $30.25 \%$ of forest land and grass land retained their original types, while $4.07 \%$ of bare land remained unchanged during this period.

Eight major combinations of landscape conversion were selected to investigate the green space losses (forest land and grass land to impervious land), green space expansion (impervious land and bare land to forest land and grass land), and green space exchange (landscape change between forest land and grass land). There was $108.86 \mathrm{~km}^{2}$ of lost green space occurred in forest land $\left(43.88 \mathrm{~km}^{2}\right)$ and grass land $\left(64.98 \mathrm{~km}^{2}\right)$. The area of green space expansion was $92.49 \mathrm{~km}^{2}$, which was mainly from transitioned impervious land $\left(67.41 \mathrm{~km}^{2}\right)$. The results show that $19.8 \mathrm{~km}^{2}$ of forest land was converted to grass land, and $34.03 \mathrm{~km}^{2}$ of grass land was converted to forest land during the same period.

\subsection{Structure and location of green spaces}

We compared the structure features and locations for different combinations of landscape conversion types (Table 4). The structural features exhibited major differences between unchanged and changed landscapes. Impervious land was the dominant landscape in the Beijing metropolis. The unchanged impervious land presented the largest area and most substantial patch size. It also exhibited the most complicated geometry and the highest connectivity. The transformed landscapes had smaller patch sizes, more regular geometries, and lower connectivity compared with the untransformed areas. There was no significant difference in landscape structure among different combinations of converted landscapes.

The landscape conversion showed some differences according to the proximity to the city center. The area of transformed landscapes accounted for $55.24 \%, 39.61 \%, 27.6 \%$, and $22.86 \%$ of the total area in the sub-regions inside of 2nd, 2nd to $3 \mathrm{rd}$, 3rd to 4th, and 4th to 5th

Table 2

Weather conditions on the dates of remote sensing image acquisitions (Source: National Meteorological Information Center, China Meteorological Administration).

\begin{tabular}{|c|c|c|c|c|c|c|}
\hline $\begin{array}{l}\text { Image acquisition date (dd/ } \\
\text { mm/yyyy) }\end{array}$ & Precipitation (mm) & $\begin{array}{l}\text { Atmospheric pressure } \\
(\mathrm{hPa})\end{array}$ & $\begin{array}{l}\text { Wind speed } \\
(\mathrm{m} / \mathrm{s})\end{array}$ & $\begin{array}{l}\text { Relative humidity } \\
\text { (\%) }\end{array}$ & $\begin{array}{l}\text { Max air temperature }\left(^{\circ}\right. \\
\text { C) }\end{array}$ & $\begin{array}{l}\text { Mean land surface } \\
\text { temperature }\left({ }^{\circ} \mathrm{C}\right)\end{array}$ \\
\hline 09/07/2002 & 0 & 998.3 & 3 & 64 & 33.3 & 30.7 \\
\hline $20 / 07 / 2009$ & 0 & 996.7 & 1.9 & 65 & 35.2 & 31.2 \\
\hline $08 / 08 / 2010$ & 0 & 1000 & 1.8 & 74 & 30.7 & 30.5 \\
\hline 08/06/ 2011 & 0 & 994.5 & 2.5 & 47 & 33 & 30.4 \\
\hline $12 / 08 / 2012$ & 0 & 1001.6 & 2.3 & 82 & 30.7 & 29.7 \\
\hline
\end{tabular}




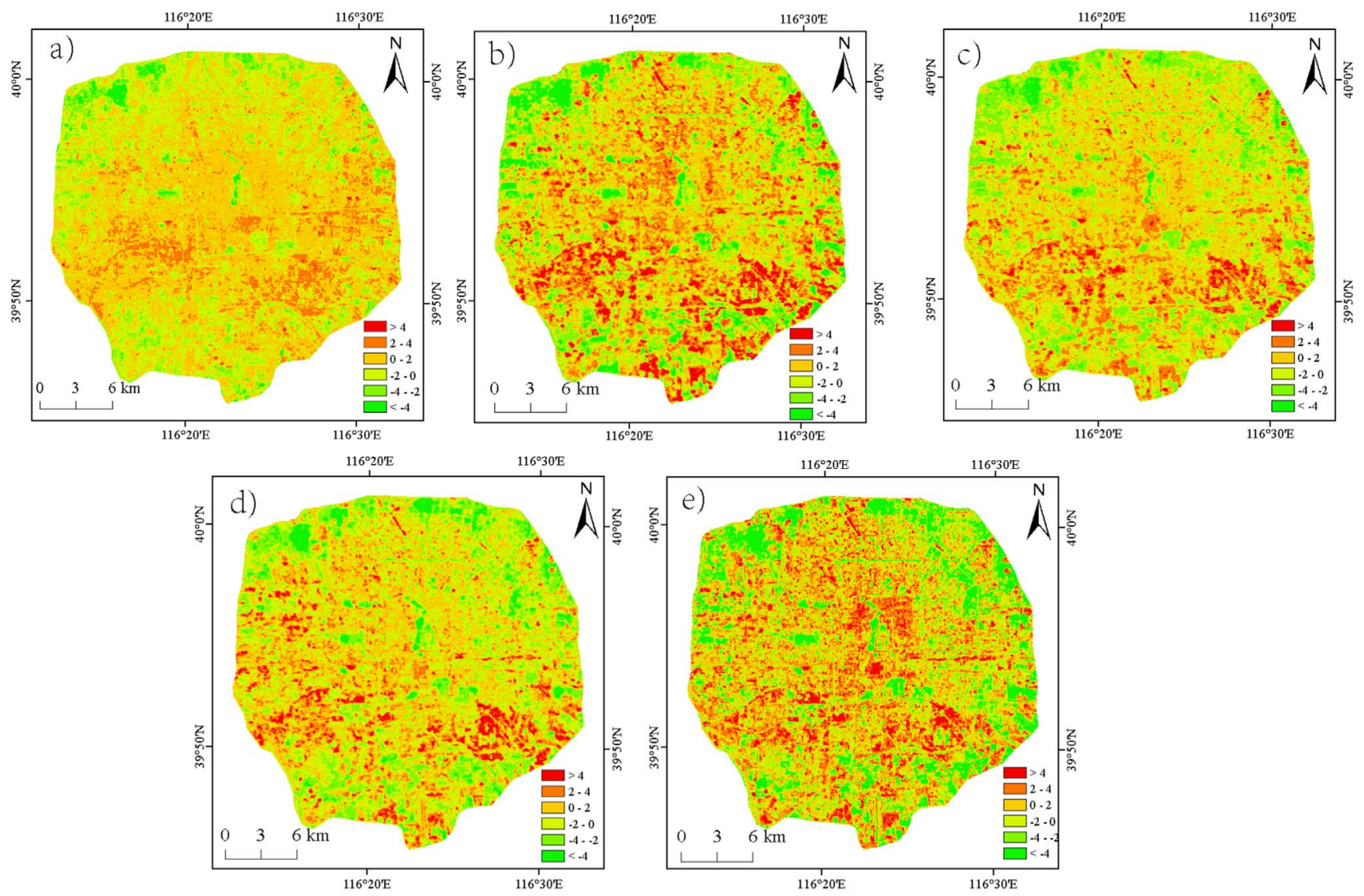

Fig. 2. Relative values of land surface temperature $\left({ }^{\circ} \mathrm{C}\right.$ ) in 2002 (a), 2009 (b), 2010 (c), 2011 (d), and 2012 (e).

Table 3

Landscape conversion from 2002 to 2012.

\begin{tabular}{|c|c|c|c|c|c|c|c|}
\hline & & \multicolumn{5}{|l|}{2012} & \multirow[b]{2}{*}{ Total area $(\mathrm{km} 2)$} \\
\hline & & Impervious land & Water & Forest land & Grass land & Bare land & \\
\hline \multirow[t]{6}{*}{2002} & Impervious land & 251.02 & 0.49 & 46.15 & 21.26 & 1.44 & 320.36 \\
\hline & Water & 0.68 & 7.73 & 0.38 & 0.51 & 0.01 & 9.31 \\
\hline & Forest land & 43.88 & 1.24 & 57.4 & 19.8 & 0.57 & 122.89 \\
\hline & Grass land & 64.98 & 1.25 & 34.03 & 44.14 & 1.52 & 145.92 \\
\hline & Bare land & 40.44 & 0.48 & 10 & 15.08 & 2.8 & 68.8 \\
\hline & Total area $(\mathrm{km} 2)$ & 401 & 11.19 & 147.96 & 100.79 & 6.34 & 667.28 \\
\hline
\end{tabular}

Table 4

Landscape structure and distribution of landscape conversions.

\begin{tabular}{|c|c|c|c|c|c|c|c|c|c|}
\hline \multirow[b]{2}{*}{ Landscape conversion } & \multicolumn{5}{|c|}{ Landscape structure } & \multicolumn{4}{|l|}{ Area $\left(\mathrm{km}^{2}\right)$} \\
\hline & PLAND (\%) & LPI (\%) & MPS (ha) & AWMSI & IJI (\%) & $\begin{array}{l}\text { Inside 2nd } \\
\text { ring-road }\end{array}$ & $\begin{array}{l}\text { 2nd - 3rd } \\
\text { ring-road }\end{array}$ & $\begin{array}{l}\text { 3rd - 4th } \\
\text { ring-road }\end{array}$ & $\begin{array}{l}\text { 4th }-5 \text { th } \\
\text { ring-road }\end{array}$ \\
\hline Unchanged Impervious & 38.11 & 27.93 & 0.546 & 153.95 & 74.1 & 38.1 & 54.36 & 71.44 & 87 \\
\hline Forest - Impervious & 6.66 & 0.02 & 0.053 & 2.38 & 59.09 & 5.35 & 9.54 & 7.24 & 21.61 \\
\hline Grass - Impervious & 9.86 & 0.59 & 0.094 & 6.2 & 68.31 & 0 & 0.21 & 10.84 & 52.88 \\
\hline Bare - Impervious & 6.14 & 0.11 & 0.089 & 3.72 & 65.99 & 0 & 0.06 & 7.29 & 32.61 \\
\hline Unchanged Forest & 8.71 & 0.23 & 0.095 & 3.91 & 72.32 & 7.83 & 13.5 & 10.92 & 25.1 \\
\hline Impervious - Forest & 7.01 & 0.01 & 0.053 & 2.12 & 56.28 & 7.61 & 13.1 & 14.04 & 11.37 \\
\hline Grass - Forest & 5.17 & 0.07 & 0.064 & 2.71 & 72.14 & 0.01 & 0.36 & 9.11 & 24.15 \\
\hline Bare - Forest & 1.52 & 0.03 & 0.037 & 2.17 & 72.11 & 0 & 0.04 & 2.98 & 6.87 \\
\hline Unchanged Grass & 6.7 & 0.16 & 0.088 & 3.32 & 75.53 & 0.04 & 0.3 & 3.06 & 40.17 \\
\hline Impervious - Grass & 3.23 & 0.03 & 0.048 & 2.25 & 66.49 & 0.68 & 2 & 3.01 & 15.52 \\
\hline Forest - Grass & 3.01 & 0.05 & 0.055 & 2.4 & 66.94 & 0.47 & 1.28 & 1.33 & 16.64 \\
\hline Bare - Grass & 2.29 & 0.04 & 0.053 & 2.55 & 70.25 & 0 & 0.01 & 0.88 & 13.95 \\
\hline Unchanged Bare & 0.43 & 0.02 & 0.035 & 1.88 & 61.41 & 0 & 0 & 0 & 2.79 \\
\hline Unchanged Water & 1.17 & 0.19 & 0.828 & 2.49 & 64.99 & 1.73 & 1.53 & 1.09 & 3.38 \\
\hline
\end{tabular}



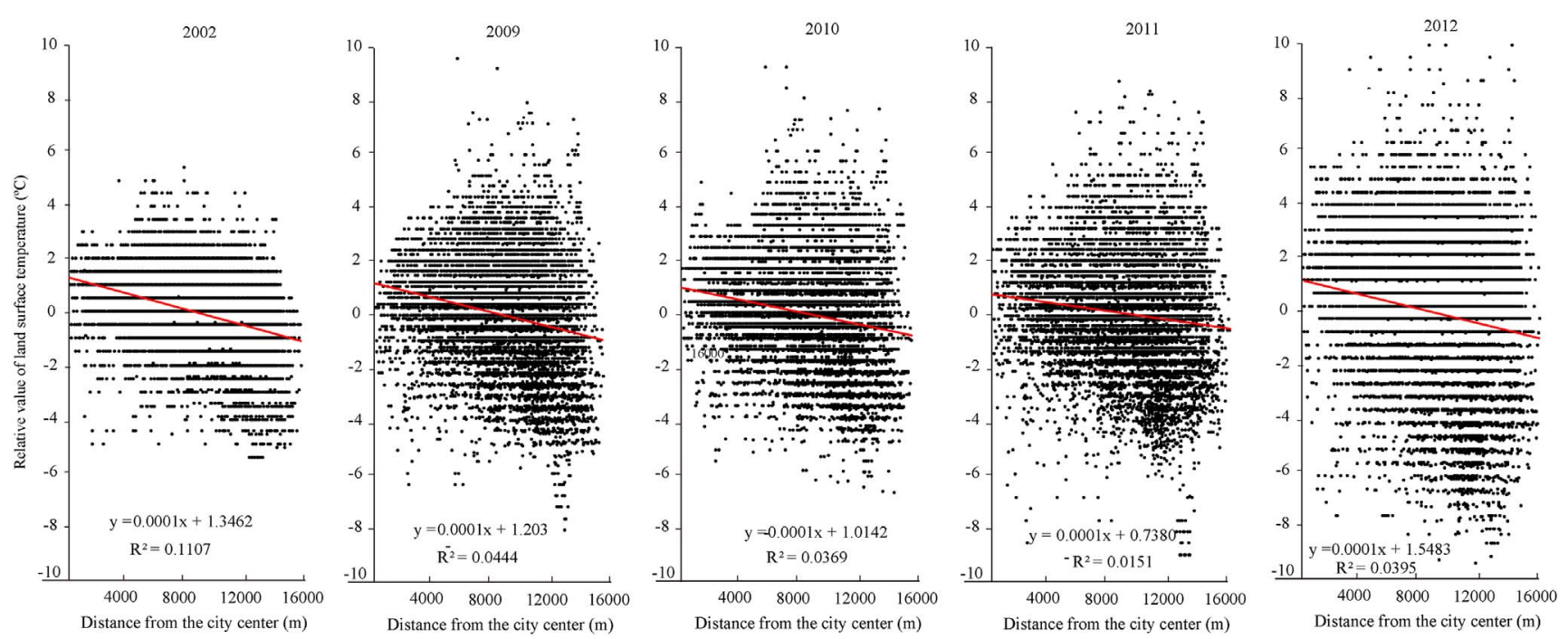

Fig. 3. Spatial gradient of land surface temperature from the city center to outskirts.

ring-roads, respectively (Table 4). Specifically, the green space losses were the dominant landscape conversion in the sub-region between the 4th and 5th ring-roads. Although the expansion of impervious land occurred in the sub-region between the 3rd and 4th ring-roads, a large amount of impervious land was converted to forest land. The net increase of forest land was $17.56 \mathrm{~km}^{2}$ in this sub-region, which is larger than the corresponding value in the sub-regions between 4th and 5th ring-roads $\left(4.14 \mathrm{~km}^{2}\right)$, the 2nd and 3rd ring-roads $\left(2.68 \mathrm{~km}^{2}\right)$, and inside of 2nd ring-road $\left(1.80 \mathrm{~km}^{2}\right)$. The conversions between impervious and forest land were dominant in the sub-region between the 2nd and 3rd ring-roads as well as those inside of 2nd ring-road.

\subsection{RLST comparison among different years}

The spatial gradient of RLST from the city center to outskirts were generated for the years of 2002, 2009, 2010, 2011, and 2012 (Fig. 3). The RLST decreased steadily $\left(0.1^{\circ} \mathrm{C} / \mathrm{km}\right)$ from the city center to outskirts in different years.

The effect of landscape conversion on the RLST was assessed by the RLST correlation among different years (Table 5). A higher proportion of unchanged area will lead to a higher correlation coefficient. The correlation coefficients of RLST between 2002 and other years ranged from 0.5 to $0.57(p<0.01)$. In contrast, the correlation coefficients of RLST among the years from 2009 to 2012 were higher and ranged from 0.72 to $0.86(p<0.01)$. This result indicates that the change of RLST could be divided into two periods: a period with a large RLST change from 2002 to 2009 and a period with a relatively small change from 2009 to 2012.

Impervious land had the highest mean RLST which then decreased in the following order: bare land, forest land, grass land, and water body (Table 6). The mean RLST of impervious land, water body, and bare land was stable from 2002 to 2012 while that of the forest land and grass land increased. The standard deviation of RLST in 2002 was $1.12,1.61,1.43,1.47$, and $1.25^{\circ} \mathrm{C}$ for impervious land, water body, forest land, grass land, and bare land, respectively. But between 2009 and 2012, the mean standard deviation of RLST was 1.78, 1.77, 1.93, 1.96 , and $1.63^{\circ} \mathrm{C}$ for impervious land, water body, forest land, grass land, and bare land, respectively. The mean value and standard deviation of the RLST exhibit a temperature increased for green spaces (forest and grass land) from 2002 to 2012.

\subsection{RLST comparison among different landscape conversions}

The RLST of unchanged landscape types was relatively stable from
Table 5

Correlations of land surface temperature among different years.

\begin{tabular}{llllll}
\hline & LST2002 & LST2009 & LST2010 & LST2011 & LST2012 \\
\hline LST2002 & 1.00 & & & & \\
LST2009 & $0.56^{* * *}$ & 1.00 & & & \\
LST2010 & $0.57^{* * *}$ & $0.86^{* * *}$ & 1.00 & & \\
LST2011 & $0.53^{* * * *}$ & $0.80^{* * * *}$ & $0.85^{* * *}$ & 1.00 & \multirow{2}{**0*}{} \\
LST2012 & $0.50^{* * * * *}$ & $0.72^{* * *}$ & $0.75^{* *}$ & $0.80^{* *}$ & 1.00 \\
\hline
\end{tabular}

${ }^{* *} p<0.01$

2002 to 2012 (Fig. 4a, b, and c). The change of mean RLST was $0.19^{\circ} \mathrm{C}$, $0.15^{\circ} \mathrm{C}$, and $0{ }^{\circ} \mathrm{C}$ for impervious, forest, and grass land, respectively. Similarly, the exchange of green spaces generated very small RLST change for forest land to grass land $\left(-0.02{ }^{\circ} \mathrm{C}\right)$ and grass land to forest land $\left(0.25^{\circ} \mathrm{C}\right)$ (Fig. $4 \mathrm{~b}$ and c). In contrast, the green space losses led to a major increase of RLST (Fig. 4a). The increase of RLST was $1.64{ }^{\circ} \mathrm{C}$ and $2.21{ }^{\circ} \mathrm{C}$ for forest land to impervious land and grass land to impervious land, respectively. The green spaces expansion decreased the RLST, which will mitigate urban heat islands (Fig. 4b, c). However, the amplitude of temperature decrease was not as significant as that of temperature increase from green space losses. The minor decrease of RLST was found in the area of green space expansion (within the range of $-1.11^{\circ} \mathrm{C}$ to $-0.67{ }^{\circ} \mathrm{C}$ ). These results indicate that the green space dynamics led to temperature mitigation and also generated a diverse temperature pattern.

Table 6

Mean value and standard deviation (SD) of relative land surface temperature $\left({ }^{\circ} \mathrm{C}\right)$.

\begin{tabular}{lllllll}
\hline & & 2002 & 2009 & 2010 & 2011 & 2012 \\
\hline Impervious land & Mean & 0.83 & 0.89 & 0.89 & 0.97 & 0.92 \\
& SD & 1.12 & 1.78 & 1.72 & 1.81 & 1.82 \\
Water & Mean & -2.97 & -3.06 & -3.09 & -3.14 & -3.08 \\
& SD & 1.61 & 1.72 & 1.84 & 1.67 & 1.83 \\
Forest land & Mean & -0.93 & -0.65 & -0.69 & -0.68 & -0.6 \\
& SD & 1.43 & 1.99 & 1.79 & 1.93 & 2.01 \\
Grass land & & & & & & \\
& Mean & -1.46 & -1.14 & -1.26 & -1.17 & -1.13 \\
Bare land & SD & 1.47 & 1.99 & 1.85 & 1.92 & 2.07 \\
& & & & & & \\
& Mean & -0.05 & -0.15 & -0.1 & -0.11 & -0.13 \\
& SD & 1.25 & 1.48 & 1.68 & 1.56 & 1.81 \\
\hline
\end{tabular}



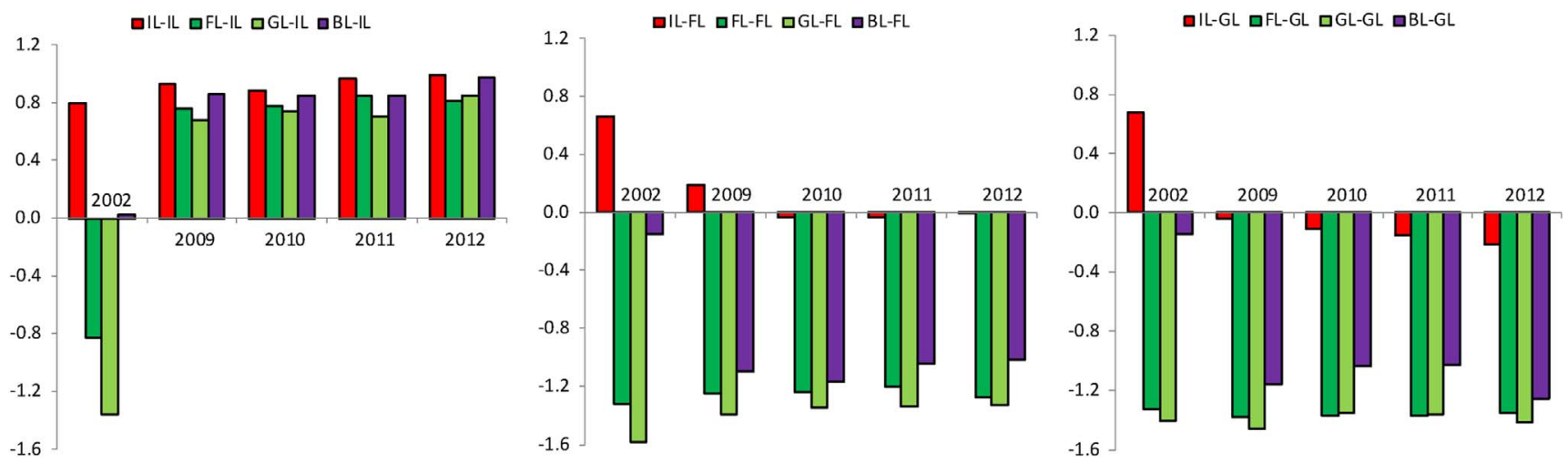


bare land.

\section{Discussion}

\subsection{Implications for urban landscape design}

Previous studies have shown that the complexity and connectivity of landscapes can enforce the LST stability due to high air exchange among different landscape units (Asgarian et al., 2015; Connors et al., 2013; Sun et al., 2013). The changed landscapes had regular geometry and isolated configuration compared with unchanged landscapes. Therefore, the change in landscape structures contributed to the LST variability, particularly between the changed and unchanged landscape types.

The loss of green spaces led to an obvious increase of LST, which agrees with the results of previous studies have exhibited (Kuang et al., 2015; Li et al., 2012). Interestingly, we found that the cooling effect of newly-planted green spaces was not as high as we expected. The standard deviation of RLST of green spaces in 2012 was larger than that before the rapid urbanization. Two factors might contribute to this phenomenon. First, the evapotranspiration of newly-planted vegetation and underlying soil was lower than that of older green spaces. A previous study has shown that different soil and vegetation can produce various evapotranspiration characteristics in Beijing (Song et al., 2015). Second, the lower surface albedo in newly-planted areas, produced by the sparse and short trees, might generate a lower cooling effect compared with older green spaces. A study found that forests in the region between the 3rd and 4th ring-roads had the lowest canopy cover compared with other regions in Beijing (Yang et al., 2005). Our study confirmed that the largest increase of forest land was between the 3rd and 4th ring-roads and that most were derived from impervious land $\left(67.41 \mathrm{~km}^{2}\right)$. This area accounts for $27 \%$ of the total area of green spaces in 2012. We selected sites using Google Earth to further exhibit the difference between the loss and expansion of green spaces (Fig. 5). The expansion of impervious areas can alter the thermal environment by modifying the land surface and underlying soil over relatively short time frames (Fig. 5, A1 and A2). In contrast, urban greening produced diverse landscape features and underlying biotopes according to the various landscape conversions. The addition of forest land (Fig. 5, B1 and B2) tended to be small and sparse compared with the original forest (Fig. 5, C2). Although impervious land was converted to green spaces, the underlying soil and biotope was usually not the prior target in the landscape design and differed from the natural land surface.

'Ecosystem-based approaches to adaptation' (EbA) have increasingly been considered in recent urban landscape design (Jones, et al., 2012). Green spaces support sustainable production of ecosystem services and foster urban resilience (McPhearson et al., 2015). A better understanding of trade-offs and relationships among different ecosystem services is crucial to promote the ecosystem services from academia to practice (Haase et al., 2014; Hansen et al., 2015; Holt et al., 2015). This study focuses on the temperature mitigation service and provides some implications for a better landscape design. First, the effect of temperature mitigation is significant in green spaces and should be one of the co-benefits for a successful EbA. Urban planning projects should concentrate on the various potential physical and intangible benefits in addition to the aesthetic benefits. Second, although the contributions of green spaces to LST have been well documented, the impact of timescale on the assessment of temperature mitigation still requires additional consideration. Further research is required to identify the potential benefits even though the temperature mitigation service may not be actualized for many years as green spaces reach a certain stage of maturity. Lastly, most studies have focused on landscape quantity over landscape quality. The landscape quality, such as evapotranspiration and albedo of vegetation and underlying soil, is highly significant for the efficiency of temperature mitigation in urban green spaces. Assessment methods of ecosystem services that only consider landscape quantity can increase the risk of overvaluing mitigation services. The Beijing municipality announced a goal of $55 \%$ total green coverage by 2020 (Yao et al., 2015). We suggest that urban greening should be implemented by increasing the quality of green areas as well as their quantity. The improvement of landscape quality is becoming more practical than a quantity increase, because land use pressures are extremely high in the Beijing metropolis.

\subsection{Limitations and potential improvements}

This study compared the LSTs among different years in Beijing. The method of invariance detection has been proposed for the relative radiometric normalization of multispectral images (Canty et al., 2004; Schott et al., 1988). We did not adopt this method in an attempt to minimize the potential errors and uncertainty introduced during these processes. The relative values of LSTs were used to capture the temperature variations that were potentially caused by different combinations of landscape conversion. The stable RLST of unchanged landscape types in different years indicated that the radiometric transformation would not significantly improve this study.

Several factors may influence our results and should be addressed in future studies. The materials that comprise impervious surfaces are varied throughout the city, but these materials are not identified in this study. Previous study showed that the mean LST of asphalt roads was approximately $2{ }^{\circ} \mathrm{C}$ higher than that of concrete roads (Kuang et al., 2015). This study did not differentiate the density and height of buildings, which could contribute to the air exchange and temperature variations in highly urbanized regions (Lindberg and Grimmond, 2011). The present study only examined the LST in summer, whereas the seasonal variability of temperature in large cities is also worthy of 


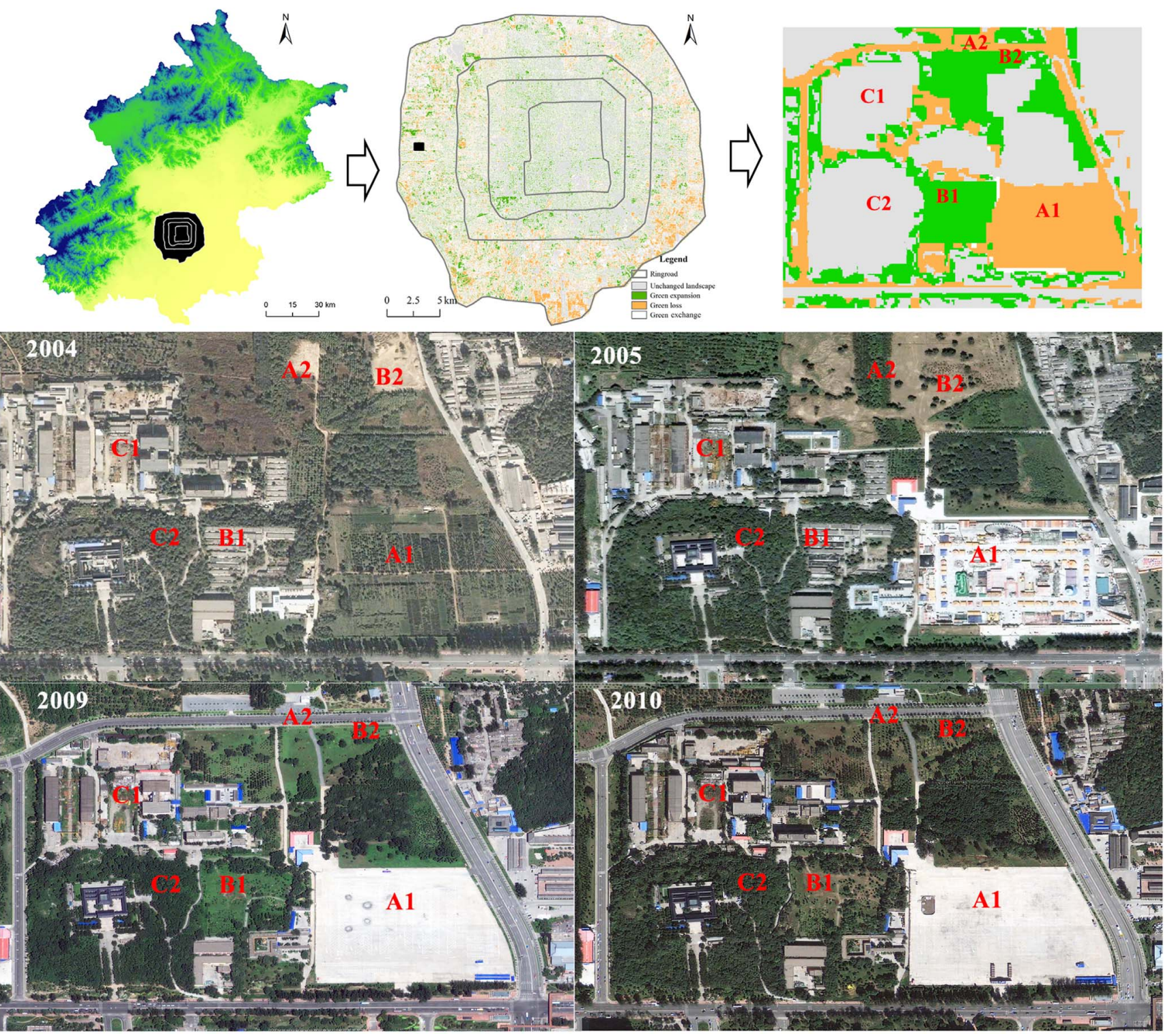

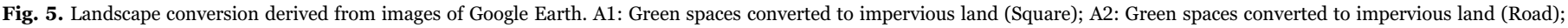
B1: Impervious land converted to green spaces; B2: Bare land converted to green spaces; C1: Unchanged impervious land; C2: Unchanged green spaces.

investigation (Buyantuyev and Wu, 2012). Further research during different seasons will be useful for examining the effects of landscape conversion on the LST change. Moreover, research has shown that the cooling effect of sulfate emissions has nearly offset the warming effects from fossil-fuel $\mathrm{CO}_{2}$, black carbon, and land-use change in China over the past three decades ( $\mathrm{Li}$ et al., 2016). Therefore, further study is needed to clarify uncertainties due to the air pollutants in the Beijing metropolis.

\section{Conclusions}

This study investigated green space dynamics and related LST change in the Beijing metropolis via multiple remote sensing images. There was obvious temperature mitigation from the conversion of impervious land to green spaces. However, the green space expansion from impervious land could lead to major diversification of thermal effects within green spaces. Although the present study might be enhanced by supplementing more detailed information on the landscape and temperature, these results expand our scientific under- standing of landscape influences on the thermal environment. This study provides useful implications for selecting appropriate indicators in the assessment of ecosystem services and generates useful results for predicting potential thermal effects of different landscape schemes in highly-urbanized regions.

\section{Acknowledgement}

The authors would like to thank Dr. Ailian Chen and Dr. Lei Yao for their assistance with remote sensing images processing. The work was supported by the Natural Science Foundation of China (41471150; 41230633).

\section{References}

Asgarian, A., Amiri, B.J., Sakieh, Y., 2015. Assessing the effect of green cover spatial patterns on urban land surface temperature using landscape metrics approach. Urban Ecosyst. 18, 209-222.

Braat, L.C., Groot, R., 2012. The ecosystem services agenda: bridging the worlds of natural science and economics, conservation and development, and public and 
private policy. Ecosyst. Serv. 1, 4-15.

Buyantuyev, A., Wu, J.G., 2012. Urbanization diversifies land surface phenology in arid environments: interactions among vegetation, climatic variation, and land use pattern in the Phoenix metropolitan region, USA. Landsc. Urban Plan. 105, $149-159$.

Canty, M.J., Nielsen, A.A., Schmidt, M., 2004. Automatic radiometric normalization of multitemporal satellite imagery. Remote Sens. Environ. 91, 441-451.

Cao, X., Onishi, A., Chen, J., Imura, H., 2010. Quantifying the cool island intensity of urban parks using ASTER and IKONOS data. Landsc. Urban Plan. 96, 224-231.

Chen, A.L., Yao, L., Sun, R.H., Chen, L.D., 2014. How many metrics are required to identify the effects of the landscape pattern on land surface temperature? Ecol. Indic. 45, 424-433.

Chen, Y.Y., Jin, G.Z., Kumar, N., Shi, G., 2013. The promise of Beijing: Evaluating the impact of the 2008 Olympic games on air quality. J. Environ. Econ. Manag. 66, 424-443.

Connors, J.P., GLletti, C.S., Chow, W.T.L., 2013. Landscape configuration and urban heat island effects: assessing the relationship between landscape characteristics and land surface temperature in Phoenix, Arizona. Landsc. Ecol. 28, 271-283.

Ding, H., Shi, W., 2013. Land-use/land-cover change and its influence on surface temperature: a case study in Beijing City. Int. J. Remote Sens. 34, 5503-5517.

Dong, R.L., 2009. Hold green Olympics to build eco-city: achieve a higher level of capital landscape of scientific development. For. Econ. 1, 20-21, (in Chinese).

Gaffin, S.R., Rosenzweig, C., Kong, A.Y.Y., 2012. Adapting to climate change through urban green infrastructure. Nat. Clim. Change 2, 704.

Haase, D., Larondelle, N., Andersson, E., Artmann, M., Borgström, S., Breuste, J. Gomez-Baggethun, E., Gren, Å., Hamstead, Z., Hansen, R., Kabisch, N., Kremer, P., Langemeyer, J., Rall, E.L., McPhearson, T., Pauleit, S., Qureshi, S., Schwarz, N., Voigt, A., Wurster, D., Elmqvist, T., 2014. A quantitative review of urban ecosystem service assessments: concepts, models, and implementation. AMBIO 43, 413-433.

Hansen, R., Frantzeskaki, N., McPhearson, T., Rall, E., Kabisch, N., Kaczorowska, A., Kain, J., Artmann, M., Pauleit, S., 2015. The uptake of the ecosystem services concept in planning discourses of European and American cities. Ecosyst. Serv. 12, $228-246$.

Holt, A.R., Mears, M., Maltby, L., Warren, P., 2015. Understanding spatial patterns in the production of multiple urban ecosystem services. Ecosyst. Serv. 16, 33-46.

Jiménez-Muñoz, J.C., Sobrino, J.A., 2003. A generalized single-channel method for retrieving land surface temperature from remote sensing data. J. Geophys. Res. 108, 4688-4695.

Jones, H.P., Hole, D.G., Zavaleta, E.S., 2012. Harnessing nature to help people adapt to climate change. Nat. Clim. Change. http://dx.doi.org/10.1038/NCLIMATE1463.

Kuang, W.H., Liu, Y., Dou, Y.Y., Chi, W.F., Chen, G.S., Gao, C.F., Yang, T.R., Liu, J.Y., Zhang, R.H., 2015. What are hot and what are not in an urban landscape: quantifying and explaining the land surface temperature pattern in Beijing, China. Landsc. Ecol. 30, 357-373.

Li, B., Gasser, T., Ciais, P., Piao, S., Tao, S., Balkanski, Y., et al., 2016. The contribution of China's emissions to global climate forcing. Nature 531, 357-361.

Li, J.X., Song, C.H., Cao, L., Zhu, F.G., Meng, X.L., Wu, J.G., 2011. Impacts of landscape structure on surface urban heat islands: a case study of Shanghai, China. Remote Sens. Environ. 115, 3249-3263.

Li, X.M., Zhou, W.Q., Ouyang, Z.Y., Xu, W.H., Zheng, H., 2012. Spatial pattern of green space affects land surface temperature: evidence from the heavily urbanized Beijing metropolitan area, China. Landsc. Ecol. 27, 887-898.

Lindberg, F., Grimmond, C.S.B., 2011. Nature of vegetation and building morphology characteristics across a city: influencing on shadow patterns and mean radiant temperatures in London. Urban Ecosyst. 14, 617-634.

Liu, H., Weng, Q.H., 2008. Seasonal variations in the relationship between landscape pattern and land surface temperature in Indianapolis, USA. Environ. Monit. Assess. $144,199-219$.

Liu, T., Yang, X.J., 2013. Mapping vegetation in an urban area with stratified classification and multiple endmember spectral mixture analysis. Remote Sens. Environ. 133, 251-264.

MaPhearson, T., Andersson, E., Elmqvist, T., Frantzeskaki, N., 2015. Resilience of and through urban ecosystem services. Ecosyst. Serv. 12, 152-156.

McGarigal, K., Marks, B.J., 1995. FRAGSTATS: Spatial Pattern Analysis Program For
Quantifying Landscape Structure (General Technical Report). U.S. Department of Agriculture, Forest Service, Pacific Northwest Research Station, Portland.

Nichol, J.E., Wong, M.S., 2008. Spatial variability of air temperature and appropriate resolution for satellite-derived air temperature estimation. Int. J. Remote Sens. 29, $7213-7223$.

Oke, T.R., 1982. The energetic basis of the urban heat island. Q. J. R. Meteorol. Soc. 108, $1-24$.

Peng, J., Xie, P., Liu, Y., Ma, J., 2016. Urban thermal environment dynamics and associated landscape pattern factors: a case study in the Beijing metropolitan region. Remote Sens. Environ. 173, 145-155.

Riechers, M., Barkmann, J., Tscharntke, T., 2016. Perceptions of cultural ecosystem services from urban green. Ecosyst. Serv. 17, 33-39.

Rotem-Mindali, O., Michael, Y., Helman, D., Lensky, I., 2015. The role of local land-use on the urban heat island effect of Tel Aviv as assessed from satellite remote sensing. Appl. Geogr. 56, 145-153.

Schott, J.R., Salvaggio, C., Volchok, W.J., 1988. Radiometric scene normalization using pseudoinvariant features. Remote Sens. Environ. 26, 1-16.

Schwarz, N., Schlink, U., Franck, U., Grobmann, K., 2012. Relationship of land surface and air temperatures and its implications for quantifying urban heat island indicators-An application for the city of Leipzig (Germany). Ecol. Indic. 18, 693-704.

Shashua-Bar, L., Hoffman, M.E., 2000. Vegetation as a climatic component in the design of an urban street: an empirical model for predicting the cooling effect of urban green areas with trees. Energy Build. 31, 221-235.

Sobrino, J., Jiménez-Muñoz, J.C., Paolini, L., 2004. Land surface temperature retrieval from LANDSAT TM 5. Remote Sens. Environ. 90, 434-440.

Song, L.S., Liu, S.M., Kustas, W.P., Zhou, J., Ma, Y.F., 2015. Using the surface temperature-albedo space to separate regional soil and vegetation temperatures from ASTER data. Remote Sens. 7, 5828-5848.

Song, Y.L., Zhang, S.Y., 2003. The study on heat island effect in Beijing during last 40 years. Chin. J. Eco-agriculture 11, 126-129, (in Chinese).

Spronken-smith, R.A., Oke, T.R., Lowry, W.P., 2000. Advection and the surface energy balance across an irrigated urban park. Int. J. Climatol. 20, 1033-1047.

Sun, R.H., Chen, L.D., 2012. How can urban water bodies be designed for climate adaptation? Landsc. Urban Plan. 105, 27-33.

Sun, R.H., Lü, Y.H., Chen, L.D., Yang, L., Chen, A.L., 2013. Assessing the stability of annual temperatures for different urban functional zones. Build. Environ. 65, 90-98.

Wang, Y., Ji, W., Yu, X.F., Xu, X.L., Jiang, D., Wang, Z.G., Zhuang, D.F., 2014. The impact of urbanization on the annual average temperature of the past 60 years in Beijing. Adv. Meteorol., 93-97. http://dx.doi.org/10.1155/2014/374987.

Weng, Q., 2009. Thermal infrared remote sensing for urban climate and environmental studies: methods, applications, and trends. ISPRS-J. Photogramm. Remote Sens. 64, 335-344.

Yang, J., McBride, J., Zhou, J.X., Sun, Z.Y., 2005. The urban forest in Beijing and its role in air pollution reduction. Urban For. Urban Green. 3, 65-78.

Yao, L., Chen, L.D., Wei, W., Sun, R.H., 2015. Potential reduction in urban runoff by green spaces in Beijing: a scenario analysis. Urban For. Urban Green. 14, 300-308.

Yu, S., Bian, L., Lin, X., 2005. Changes in the spatial scale of Beijing UHI and urban development. Sci. China Ser. D. - Earth Sci. 48 (z2), 97-106.

Yuan, F., Bauer, M., 2007. Comparison of impervious surface area and normalized difference vegetation index as indicators of surface urban heat island effects in Landsat imagery. Remote Sens. Environ. 106, 375-386.

Zhang, H., Qi, Z.F., Ye, X.Y., Cai, Y.B., Ma, W.C., Chen, M.N., 2013. Analysis of land use/ land cover change, population shift, and their effects on spatiotemporal patterns of urban heat islands in metropolitan Shanghai, China. Appl. Geogr. 44, 121-133.

Zhang, X.M., Qian, W., 2010. The implications of "green Olympics" to the environmental project investment of Beijing. Ecol. Environ. 4, 154-156, (in Chinese).

Zhao, L., Lee, X., Smith, R., Oleson, K., 2014. Strong contributions of local background climate to urban heat islands. Nature 511, 216-219.

Zhou, D., Zhao, S., Liu, S., Zhang, L., Zhu, C., 2014. Surface urban heat island in China's 32 major cities: spatial patterns and drivers. Remote Sens. Environ. 152, 51-61.

Zhou, W.Q., Huang, G.L., Cadenasso, M.L., 2011. Does spatial configuration matter? Understanding the effects of land cover pattern on land surface temperature in urban landscapes. Landsc. Urban Plan. 102, 54-63. 